\title{
Investigating the Influence of Some Environmental Factors on the Stability of Paracetamol, Naproxen, and Diclofenac in Simulated Natural Conditions
}

\author{
Aneta Sokól, Katarzyna Borowska, Joanna Karpińska* \\ Institute of Chemistry, University of Białystok, Ciolkowskiego 1K, 15-245 Bialystok, Poland
}

Received: 17 March 2016

Accepted: 19 July 2016

\begin{abstract}
Many factors influence the persistence of traces of pharmaceuticals in aqueous environments. Most important are the intensity of light and the presence of inorganic ions as well as organic matter. We studied the impact of some environmental factors (humic acids, $\mathrm{NO}_{3}^{-}$and $\mathrm{NO}_{2}^{-}$ions, solar light intensity, and ambient $\mathrm{pH}$ ) on the stability and kinetics of photo-reactions of paracetamol, naproxen, and diclofenac. It was stated that paracetamol was photoresistant, while naproxen and diclofenac were photoliable. An addition of $\mathrm{NO}_{3}^{-}$and $\mathrm{NO}_{2}^{-}$ions or humic acid strongly inhibited photodecomposition of paracetamol. Their presence in the solution of naproxen slowed down its decomposition, while in the case of diclofenac their influence on the kinetics of the photoreaction was neglected. The effect of the presence of the natural matrix on the photoreaction of the studied pharmaceuticals was checked. The influence of certified reference material - a water sample from the Grand River (Canada) and a sample of treated municipal waste - was examined. We observed that the matrix created by treated municipal waste acted as a photo-sensitizer. Its presence in solution accelerated the photodecomposition of all studied compounds.
\end{abstract}

Keywords: paracetamol, naproxen, diclofenac, photodegradation, kinetics of photodegradation

\section{Introduction}

Pharmaceutical drugs form a large and diversified group of organic substances. Presently, more than 3,000 active substances are offered through European Union markets [1]. This mass consumption of drugs has given rise to a new environmental issue, namely the appearance of pharmaceuticals and their metabolites in the natural

*e-mail: joasia@uwb.edu.pl environment [1-2]. Consumed drugs are excreted from the organism in an unchanged form or in the form of metabolites [3-4]. Other sources of environmental pollution with biologically active substances include households, animal breeding farms, pharmaceutical industry facilities, and hospitals and diagnostic centers [5]. Stability of pharmaceuticals is the key factor influencing the potential threat they pose to the ecosystem [6-7]. In water environments, the substances are distributed mostly by means of water transport [8-9]. Consequently, the presence of pharmaceuticals has an adverse effect on all 
organisms living in natural waters [10]. On top of that, it constitutes a serious hazard to human health [11]. In surface waters, pharmaceuticals undergo sorption and desorption on molecules of organic matter and sediments, transformations by bacteria, and direct or indirect photodegradation in the surface layers $[1,12]$. Stability of pharmaceuticals in water environments depends on a number of factors, in particular on the intensity of light, but also on the presence of suspended organic matter and the concentration of inorganic ions such as $\mathrm{CO}_{3}{ }^{2-}, \mathrm{HCO}_{3}^{-}$, $\mathrm{NO}_{3}^{-}, \mathrm{Fe}^{2+}$, and $\mathrm{Fe}^{3+}[13-14]$.

The aim of the presented study was to analyze the impact of selected environmental factors (humic acids, $\mathrm{NO}_{3}^{-}$ and $\mathrm{NO}_{2}^{-}$ions, solar light intensity, and ambient $\mathrm{pH}$ ) on the stability and kinetics of photo-reactions in three compounds belonging to the family of non-steroidal antiinflammatory drugs (NSAID): paracetamol, naproxen, and diclofenac (Fig. 1).

These substances were chosen from among a large group of NSAIDs, because they can be qualified, right after antibiotics, as the most frequently used pharmaceutical drugs [15-16]. For instance, some 30 trillion NSAID tablets are sold each year in the USA, whereas some 70 billion are prescribed by physicians. In Poland, only in the year 2004 there were about 34 million packs of the medi-

a)<smiles>CC(=O)Nc1ccc(O)cc1</smiles>

b)<smiles>COc1ccc2cc(C(C)C(=O)O)ccc2c1</smiles>

c)<smiles>O=C(O)Cc1ccccc1Nc1c(Cl)cccc1Cl</smiles>

Fig. 1. Chemical structures of studied compounds: a) paracetamol, b) naproxen, c) diclofenac. cines in question sold [16]. Needless to say, the drugs are commonly reported to be present in surface waters and waste, as well as in treated wastewater [17-19].

In particular, the presence of paracetamol in treated wastewater from sewage treatment plants was denoted to be between $20 \mathrm{ngL}^{-1}$ and $4.3 \mu \mathrm{gL}^{-1}$ [18]. It turns out that its concentration in surface water can reach up to $78.17 \mu \mathrm{gL}^{-1}$, significantly exceeding the permissible limit $\left(9.2 \mu \mathrm{gL}^{-1}\right)$ [18]. As such, paracetamol present in the environment exhibits toxic properties. Tests carried out on various species of algae, fish embryos, luminescent bacteria, and ciliates proved that paracetamol can seriously endanger these organisms. Incidentally, Daphnia magna turned out to be the most susceptible of the investigated species; in the case of these freshwater arthropods $\mathrm{EC}_{50}$ $\left(\mathrm{LD}_{50}\right)$ equalled between 30.1 and $50 \mathrm{mgL}^{-1}$ [18].

Paracetamol is a moderately photosensitive compound. The determined value of its irradiation half-life equals 40 to $350 \mathrm{~h}$. This value considerably decreases to 16-26 $\mathrm{h}$ during the biodegradation of the compound in water environments [20].

The second of the analyzed compounds, naproxen, occurs in the natural environment in relatively low concentrations [21-22]. Research conducted by German scientists showed that naproxen was found in rivers in Germany at the maximum level of $0.30-0.42 \mu \mathrm{gL}^{-1}$ [23]. Nonetheless, this compound was also detected in the surface waters of Canada and the USA [24] in concentrations ranging from $37 \mathrm{ngL}^{-1}$ to $63 \mathrm{ngL}^{-1}$. In treated wastewater, this drug was denoted at a concentration of $106 \mathrm{ngL}^{-1}$ [24], with more than $1.0 \mathrm{~g}$ of the substance a day introduced into the original wastewater [24], which implies that wastewater treatment plants are capable of achieving a daily overall elimination constant rate of 0.051 day $^{-1}$ [24].

With regard to diclofenac, this drug belongs to the most frequently detected in waters. The concentrations denoted in treated wastewater reach several $\mu \mathrm{gL}^{-1}$, e.g., Italy $0.2-0.5 \mu \mathrm{gL}^{-1}$ [25], Germany up to $2.1 \mu \mathrm{gL}^{-1}[26]$, Canada $0.07-0.25 \mu \mathrm{gL}^{-1}$ [27], and Spain $0.72 \mu \mathrm{gL}^{-1}$ [28]: In Poland, the recorded levels of diclofenac concentrations were $0.300-0.528 \mu \mathrm{gL}^{-1}$ [29]. In 2008 research was carried out to identify the presence of commonly used medicines in Warta River waters and in municipal waste. Accordingly, in the Warta waters diclofenac was detected at a level of 17-486 $\mathrm{ngL}^{-1}$, whereas in untreated municipal waste it was at the level of 2,000-4,000 $\mathrm{ngL}^{-1}$ [30], and in treated waste at the level of $1,000-3,000 \mathrm{ngL}^{-1}$. Thus, the quoted figures imply that the efficiency of diclofenac removal in the course of regular waste treatment amounts to only $21-40 \%$ [31]. Diclofenac present in the natural environment is practically non-volatile and not susceptible to hydrolysis [32]. It undergoes sorption on sediments with difficulty. By contrast, it is vulnerable to photolysis and biodegradation. The drug subjected to direct photodegradation in natural waters undergoes decomposition within several dozen minutes, depending on latitude and the sunlight intensity [12].

The purpose of the present study was to investigate the impact of selected environmental factors on the 
kinetics of photodecomposition of paracetamol, naproxen, and diclofenac - in both laboratory and simulated environmental conditions.

\section{Materials and Methods}

\section{Reagents}

All solutions were prepared using Milli-Q water. Paracetamol, diclofenac, and naproxen were in the form of sodium salt, and humic acids were purchased from Sigma-Aldrich, Poland.

Others chemicals used in our experiments were sulfuric acid, sodium hydroxide, potassium nitrate, sodium nitrite, acetonitrile, $80 \%$ acetic acid, and methanol $(\mathrm{POCH}$ SA., Poland). Certified Reference Material ION-96.3 - a water sample from the Grand River in Canada - was supplied by Canada's National Water Research Institute.

\section{Equipment and Research Procedures}

All spectrophotometric determinations were done using a Hitachi U-2800A spectrophotometer at scan speed 1,200 $\mathrm{nm} \cdot \mathrm{min}^{-1}$ and spectral bandwidth $1.5 \mathrm{~nm}$.

An Elmetron CP-501 pH meter (Poland) was used to measure the $\mathrm{pH}$ of studied solution.

We used a SUNTEST CPSț solar light simulator (ATLAS, USA) emitting radiation in the range of 300-800 nm for experiments in simulated natural conditions.

Light intensity was determined using a Reinecke potassium salt $\left(\mathrm{K}\left[\mathrm{Cr}\left(\mathrm{NH}_{3}\right)_{2}(\mathrm{SCN})\right] \cdot \mathrm{H}_{2} \mathrm{O}\right)$ actinometer. Fifty $\mathrm{ml}$ of mixture containing $5 \cdot 10^{-4} \mathrm{molL}^{-1}$ solution of $\left(\mathrm{K}\left[\mathrm{Cr}\left(\mathrm{NH}_{3}\right)_{2}(\mathrm{SCN})\right] \cdot \mathrm{H}_{2} \mathrm{O}\right), 1.5 \mathrm{molL}^{-2} \mathrm{Fe}\left(\mathrm{NO}_{3}\right)_{3} \cdot 9 \mathrm{H}_{2} \mathrm{O}$, and $1.6 \cdot 10^{-1} \mathrm{molL}^{-1} \mathrm{HNO}_{3}$ were placed into a crystallization dish with a surface of $28.26 \mathrm{~cm}^{2}$ area open to atmosphere and exposed to a light source of a solar light simulator for $10 \mathrm{~min}$. The light power used was $750 \mathrm{Wm}^{-2}$. The photo-released thiocyanate was monitored by measurements of absorbance at $456 \mathrm{~nm}$ at various periods of time. The quantum yield of Reinecke's potassium salt in aqua solution is 0.3 at $365 \mathrm{~nm}$ [33]. The determined number of quanta absorbed by the actinometer was $\left(\mathrm{I}_{\mathrm{a}}\right)=8.99 \cdot 10^{19}$. The radiant power $(\mathrm{P})$ absorbed during the time interval of irradiation $(\mathrm{t}=600 \mathrm{~s})$ was $8.16 \cdot 10^{-2}(\mathrm{~W})$.

Given that the exposure of surface area of the actinometer was equal to $28.26 \mathrm{~cm}^{2}$, the fraction of the absorbed light power per unit surface area, generally called intensity of the radiation, $\left(\mathrm{E}_{\mathrm{s}}\right)$ was determined as $\mathrm{E}_{\mathrm{s}}=28.88\left(\mathrm{Wm}^{-2}\right)$.

\section{Preparation of the Standard Solution of Paracetamol}

The standard solution of paracetamol with a concentration of $10^{-2} \mathrm{molL}^{-1}$ was prepared by dissolving a proper analytical weighed amount in ethanol (analytically pure) in a $50 \mathrm{ml}$ volumetric flask. Working solutions of desired concentrations were set up each day of the experiment by diluting an appropriate measure of the standard solution in double-distilled water.

\section{Preparation of the Standard Solutions of Naproxen and Diclofenac}

The standard solutions of naproxen and diclofenac with concentrations of $10^{-2} \mathrm{molL}^{-1}$ were prepared by dissolving proper analytical weighed amounts of each of these substances in double-distilled water in a $50 \mathrm{ml}$ volumetric flask. Working solutions of desired concentrations were set up each day of the experiment by diluting the standard solutions in a suitable manner.

\section{Calibration Curves for the Analyzed Drugs}

To plot calibration curves for the analyzed drugs, we prepared working solutions with concentrations of $2.5 \cdot 10^{-6}, 5 \cdot 10^{-6}, 7.5 \cdot 10^{-6}, 1 \cdot 10^{-5}, 2.5 \cdot 10^{-5}, 5 \cdot 10^{-5}$, and $7.5 \cdot 10^{-5} \mathrm{molL}^{-1}$. Absorption spectra were registered in the $190-350 \mathrm{~nm}$ range against the reference spectrum of double-distilled water. The values of absorbance were recorded at analytical wavelengths (240 nm for paracetamol, $226 \mathrm{~nm}$ for naproxen, $274 \mathrm{~nm}$ for diclofenac). Table 1 presents the results.

\section{Analysis of Photodecomposition Kinetics}

The following procedure was employed to establish the kinetics of photodecomposition for the investigated drugs, and to determine the influence of environmental factors on the photodegradation process: a $50 \mathrm{ml}$ volume of the drug solution with concentration of $510^{-5}$ molL $^{-1}$ was transferred to a crystallizing dish and put in the chamber of a solar radiation simulator. The solution was then irradiated for 120 minutes. Every 10 minutes the irradiation was interrupted, and its UV spectrum was recorded in the range 190-340 nm. The concentration of the analyzed compound prevalent in the solution at a given moment was read from the relevant calibration curve. The first-order kinetics model was assumed for the observed processes. The observed

Table 1. Equations of calibration graphs used for spectrophotometric determination of current concentrations of examined compounds.

\begin{tabular}{|c|c|c|c|}
\hline Studied compound & Linearity range $/ \mathrm{molL}^{-1}$ & Equation of calibration graph & $\mathrm{LOD} / \mathrm{molL}^{-1}$ \\
\hline Paracetamol & $4.4310^{-6}-7.510^{-5}$. & $\mathrm{y}=1.0610^{4} \mathrm{x}+1.7010^{-2}$ & $1.3310^{-6}$ \\
\hline Naproxen & $1.8910^{-5}-5.010^{-5}$ & $\mathrm{y}=5.4110^{4} \mathrm{x}+9.1210^{-2}$ & $2.510^{-6}$ \\
\hline Diclofenac & $5.9310^{-6}-5.510^{-5}$ & $\mathrm{y}=8.8510^{3} \mathrm{x}-2.2010^{-2}$ & $1.7710^{-6}$ \\
\hline
\end{tabular}


first-order reaction rate constant was determined graphically using the following equation: $\ln \left(\mathrm{c}_{0} / \mathrm{c}\right)=\mathrm{k} \mathrm{t}$, where $\mathrm{c}_{0}$ is the initial concentration of examined compound and $\mathrm{c}$ is its concentration at a given moment $(\mathrm{t})$. The slope of the obtained graph is the value of the observed rate constant.

\section{Chromatographic Analysis}

We used a chromatographic system (Thermo Separation) consisting of a UV 3000 3D Spectra System, a P2000 low-gradient pump, an SCM Thermo Separation vacuum membrane degasser, and a Rheodyne loop injector (20 mL). ChromQuest Chromatography Data system software for Windows NT was applied for the acquisition and storage of data. $20 \mu \mathrm{L}$ of an investigated solution was injected into the ODS-2 SUPELCOSIL chromatographic column (Suplelco, USA). The mobile phase used in the chromatography consisted of acetonitrile and water (its $\mathrm{pH}$ set to 2.5 with the use of concentrated orthophosphoric acid) in the ratio of 25:75 (v/v) in the case of paracetamol solutions. The flow rate of the mobile phase was $2 \mathrm{ml} \mathrm{min-}$ ${ }^{1}$, and retention time for paracetamol was $1.26 \mathrm{~min}$.

As regards naproxen and diclofenac, the mobile phase consisting of acetonitrile and acetic acid with the concentration of $6.910^{-3} \mathrm{~mol} \mathrm{~L}^{-1}$ and $\mathrm{pH} 4$ combined in the ratio of 35:65 (v/v). In this case we used a flow rate of $1 \mathrm{ml} \mathrm{min}{ }^{-1}$. The obtained retention times were $15 \mathrm{~min}$ for naproxen and $8.9 \mathrm{~min}$ for diclofenac.

\section{Results and Discussion}

\section{Preliminary Analysis}

Research concerning the photodegradation of paracetamol, naproxen, and diclofenac commenced with the analysis of spectral characteristics of these compounds. Absorption spectra in the range 190-340 nm for the solutions with concentration of $5 \cdot 10^{-5} \mathrm{molL}^{-1}$ were registered. $\mathrm{pH}$ measurements of the working solutions

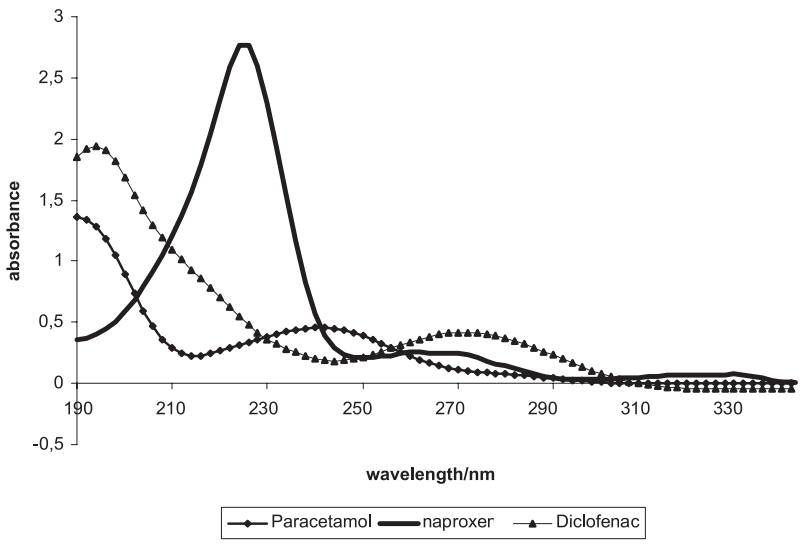

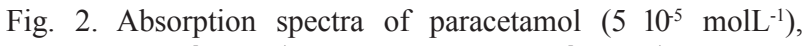
naproxen $\left(510^{-5} \mathrm{molL}^{-1}\right)$, and diclofenac $\left(510^{-5} \mathrm{molL}^{-1}\right)$. equaled 6.9 in the cases of paracetamol and naproxen, and 6.1 in the case of diclofenac. The spectra of the solutions were recorded with reference to the spectrum of doubledistilled water (Fig. 2).

Essentially, the spectrum of paracetamol includes two absorption bands, the first one at $190 \mathrm{~nm}$ and the second, less intense, at $240 \mathrm{~nm}$. As for naproxen, it has a very strong absorption band at $226 \mathrm{~nm}$, a less intense one at $270 \mathrm{~nm}$, and a weak one at $330 \mathrm{~nm}$. The spectrum of diclofenac features two absorption bands: an intense one at $200 \mathrm{~nm}$ and a much less intense one at $274 \mathrm{~nm}$.

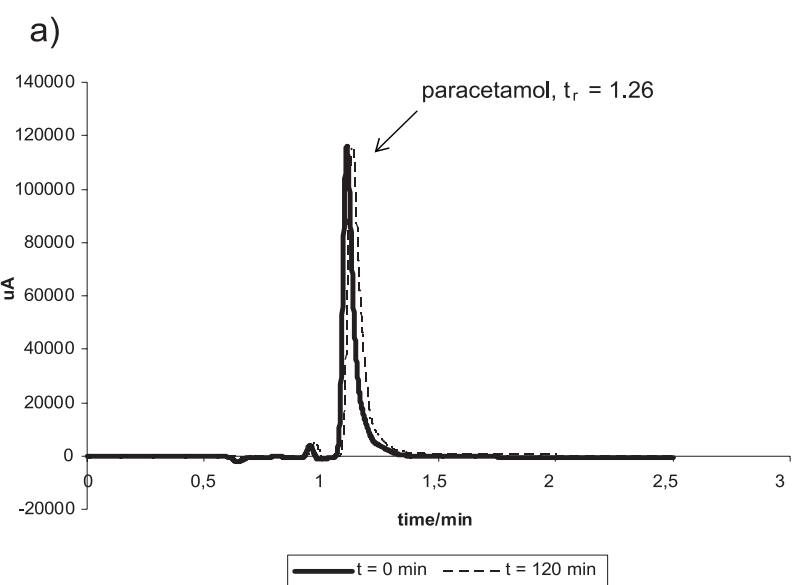

b)
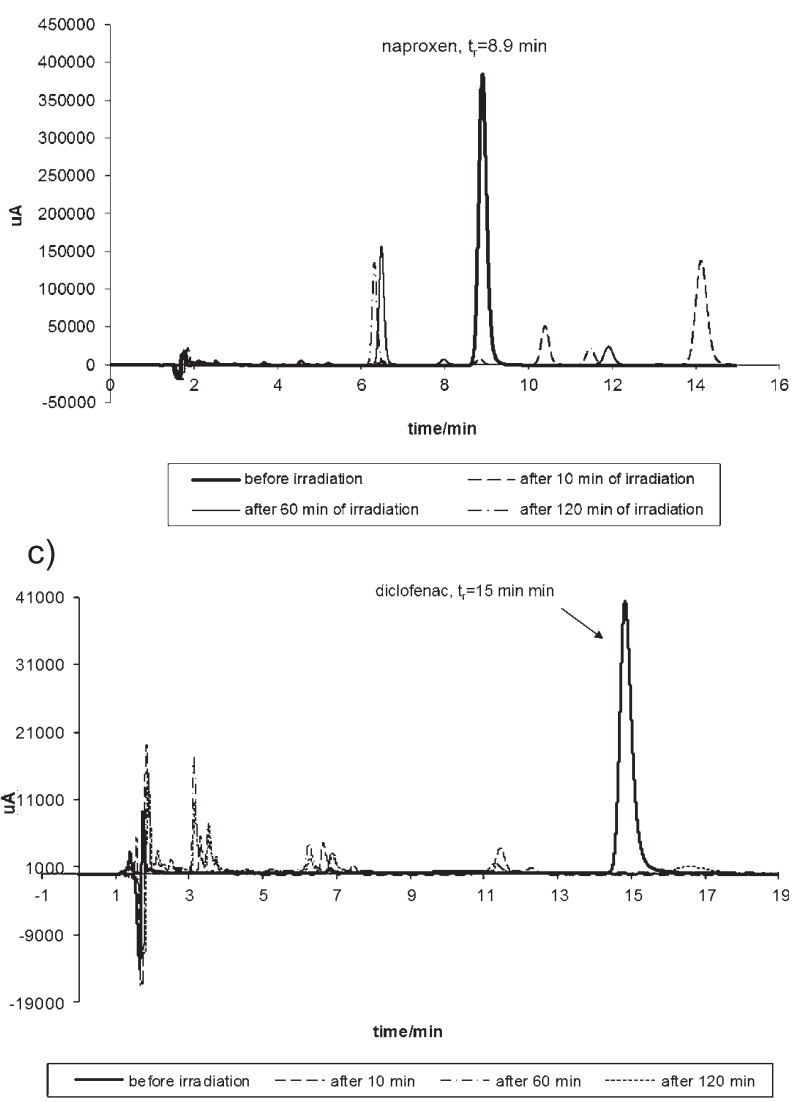

Fig. 3. Chromatograms of non-irradiated and irradiated laboratory solution of a) paracetamol, b) naproxen, and c) diclofenac; $\mathrm{c}=510^{-5} \mathrm{~mol} \mathrm{~L}^{-1}$ (— before radiation; - - after $120 \mathrm{~min}$ of radiation). 
Our investigation of photodegradation processes started with chromatographic analysis of the discussed compounds in order to address the question of whether paracetamol, naproxen, and diclofenac are photosensitive and how complex the potential process of their photodecomposition is. Accordingly, the solutions of the scrutinized compounds that had been irradiated by stimulated solar light with intensity of $750 \mathrm{~W} \mathrm{~m}^{-2}$ were injected into the chromatographic column. Chromatograms of non-irradiated solutions, as well as the solutions after 10, 20, 60, and 120 minutes of irradiation were recorded. On their basis it could be concluded that paracetamol is a non-photosensitive compound, i.e. its chromatographic peak did not alter. Additionally, no new peaks were observed (Fig. 3a). The two other drugs turned out to be photosensitive, as their chromatograms registered after 10, 20, 60, and 120 minutes of irradiation exhibited new peaks related to the products of their photodecomposition. In particular, it was concluded that naproxen underwent complete photodegradation already after 10 minutes, and that the ensuing products are photosensitive as well. After 120 minutes of irradiation only two photoproducts with retention times 6.5 and 11.6 minutes remained (Fig. 3b).

HPLC analysis proved that diclofenac also decomposed completely within the first 10 minutes of irradiation. In this case, the relevant chromatograms showed that the process of decomposition is extremely complex. Specifically, after 10 minutes of irradiation as much as five new products of photodecomposition appeared; these had retention times of $3.2 \mathrm{~min}, 3.6 \mathrm{~min}, 6.4 \mathrm{~min}, 10 \mathrm{~min}$, and $11.5 \mathrm{~min}$. Moreover, the chromatograms recorded after the longer periods of irradiation indicated that the peaks were growing weaker over time, suggesting photosensitivity of the products and warranting further transformations (Fig. 3c).

\section{Investigation of the Influence of Selected Environmental Factors on the Kinetics of Photodegradation of Paracetamol, Naproxen, and Diclofenac}

The significance of several parameters important from the perspective of kinetics of photoreactions occurring in a water environment was scrutinized. The following determinants were taken under consideration: intensity of the simulated solar radiation, environment $\mathrm{pH}$, concentrations of $\mathrm{NO}_{3}{ }^{-}$and $\mathrm{NO}_{2}{ }^{-}$ions, and the presence of humic acids. The observation was directed at determining those factors that have real impact on the lifetime of the discussed drugs in water environments. The progress of photochemical reactions was monitored by means of spectrophotometric techniques, denoting the absorbance of the drugs at wavelengths of 240, 226, and $274 \mathrm{~nm}$, respectively, for paracetamol, naproxen, and diclofenac. In the analysis, the first-order model of kinetics was assumed. Thus, the results concerning the reaction kinetics achieved with the spectrophotometric method lend information about the mean rate of the process, i.e., the resultant rate of decomposition of the main compound and the appearance and disappearance of its photoproducts. The relevant figures are presented in Table 2.

\section{Influence of Light Intensity}

The first of the considered aspects was the influence of simulated solar light on the photodegradation of paracetamol, naproxen, and diclofenac. In fact, two values of intensity were used: 500 and $750 \mathrm{Wm}^{-2}$, and the irradiated working solutions of paracetamol, naproxen, and diclofenac had the concentrations of $5 \cdot 10^{-5} \mathrm{molL}^{-1}$. The natural $\mathrm{pH}$ of the studied solutions without any addition of acids or bases equaled 6.9,6.9, and 6.1, respectively. The actual concentration in a given moment was determined by relying on the absorbance measurements in reference to double-distilled water.

In effect of the above experiments it was established that paracetamol was resistant to photodegradation by solar light. The increase of lamp power did not cause any changes in its spectral characteristics. During analysis, its spectrum remained almost unchanged (Fig. 4a), and the intensity of light only to a negligible degree was reflected by the transformations of absorbance. By contrast, naproxen turned out to be photosensitive (Fig. $4 \mathrm{~b})$. In the course of irradiation, its absorbance decreased at $226 \mathrm{~nm}$. Moreover, the rate of the reaction increases with the growing intensity of the simulated light. These conclusions are illustrated by the data in Table 2. Also, diclofenac underwent photodegradation in the simulated solar light. In its decomposition a product appeared whose absorbance maximum corresponded to $242 \mathrm{~nm}$. Unfortunately, its absorbance band largely overlapped with the absorbance band of the original compound (Fig. $4 \mathrm{c}$ ). Additionally, it was noticed that the photoproduct of diclofenac was also photosensitive, and underwent further transformation during the continued irradiation.

Influence of the remaining environmental factors was evaluated using the intensity of $750 \mathrm{~W} \mathrm{~m}^{-2}$ only.

\section{Influence of $\mathrm{pH}$ on the Kinetics of Photodegradation of the Analyzed Drugs}

To examine the influence of environmental $\mathrm{pH}$ on photodegradation of paracetamol, naproxen, and diclofenac, we concocted proper working solutions of these drugs with concentrations of $5 \cdot 10^{-5} \mathrm{molL}^{-1}$ and their $\mathrm{pH}$ adjusted by the addition of suitable volumes of $0.05 \mathrm{molL}^{-1} \mathrm{NaOH}$ and $0.1 \mathrm{molL}^{-1} \mathrm{H}_{2} \mathrm{SO}_{4}$. Principally, we analyzed solutions with $\mathrm{pH}$ of $2,4,8$, and 10 . The obtained working solutions were irradiated in a solar radiation simulator for 120 minutes, interrupting the process every 10 minutes to take down the value of absorbance. The outcomes of the experiment are gathered in Table 2. Essentially, we figured out that environmental $\mathrm{pH}$ did not affect the photodegradation of paracetamol. The compound appeared to be photoresistant in the assumed $\mathrm{pH}$ interval. But in the cases of naproxen and diclofenac, it was decided that low $\mathrm{pH}$ value facilitated the decomposition of the drugs. For instance, naproxen 


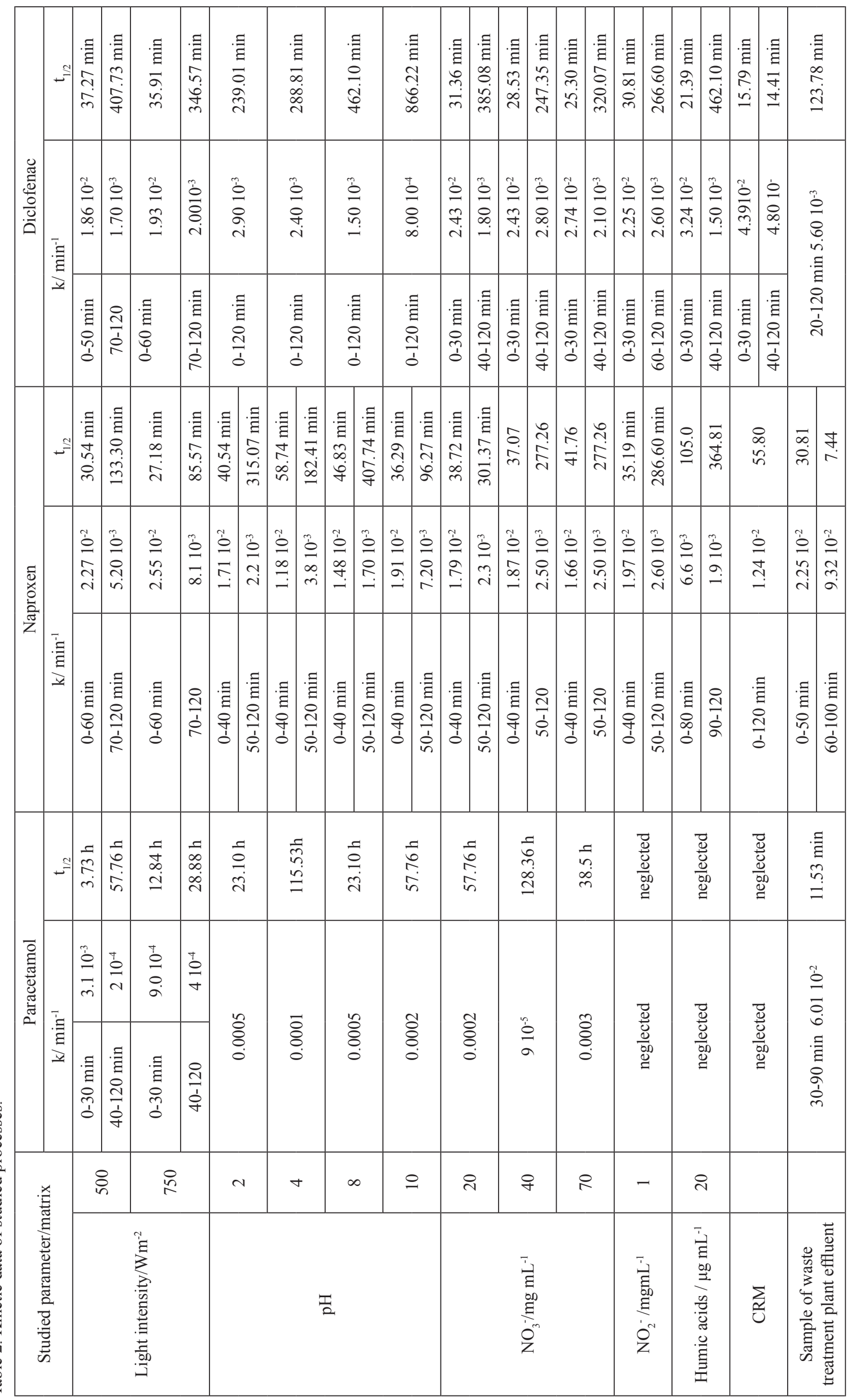


decomposed ca. 1.3 times quicker when the ambient $\mathrm{pH}$ was 2 in comparison to cases with high $\mathrm{pH}$ values (Table 2). Furthermore, it could be noted that the photodegradation of naproxen occurred intensively in the course of the initial 40 minutes, but later its pace slowed. For diclofenac, the impact of $\mathrm{pH}$ on its stability was comparable to the case of naproxen, i.e., low $\mathrm{pH}$ ( 2 and 4 ) values expedited its photodecomposition. Taking into account the observed acceleration in the rate of direct photolysis, it can be assumed that $\mathrm{H}^{+}$ions act as a catalyst of the chain of photochemical transformation reactions leading to the generation of degradation products. Additionally, the observed behavior could be explained by the different

a)

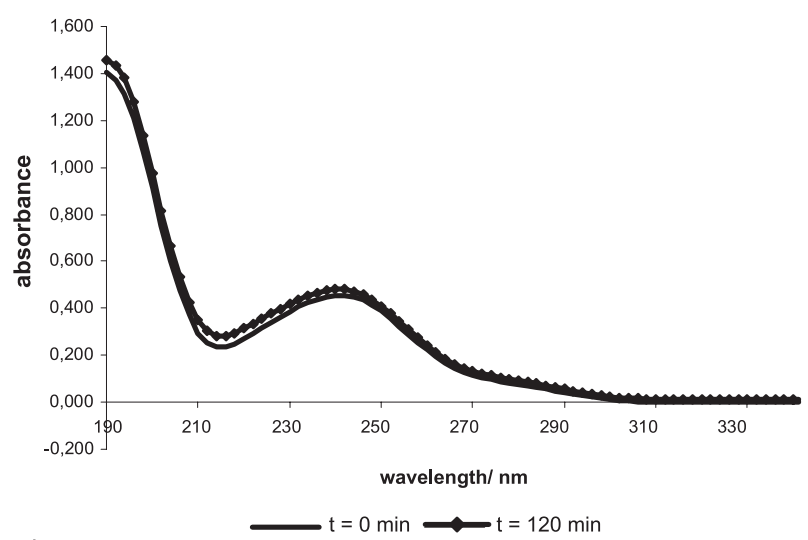

b)

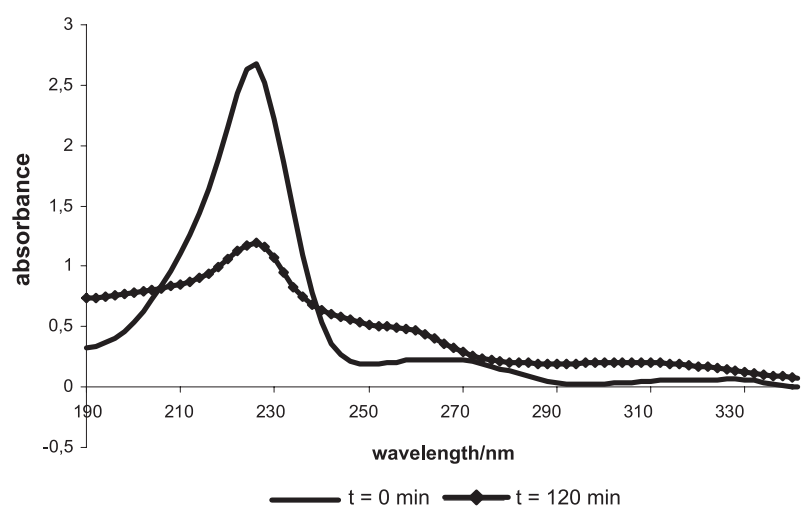

c)

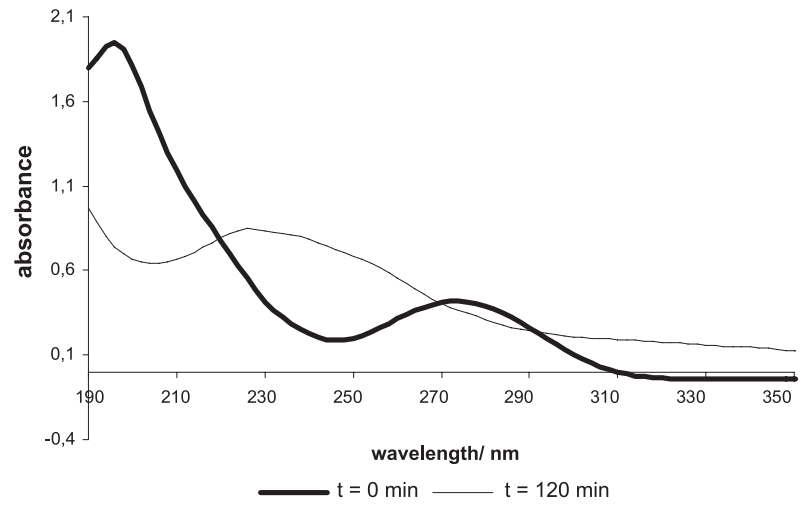

Fig. 4. Changes in spectral characteristic of studied drugs after 120 min of irradiation: a) paracetamol, b) naproxen, and c) diclofenac (power source $750 \mathrm{~W} \mathrm{~m}^{-2}, \mathrm{c}=510^{-5} \mathrm{~mol} \mathrm{~L}^{-1}$ ). spectral nature of acid-based speciation. At acidic $\mathrm{pH}$ $(<7)$, diclofenac and naproxen as week acids are present in the solution in free acid form. Both forms - ionized and neutral - can be characterized by different quantum yields, which can additionally explain the observed increase in decomposition rate.

\section{Influence of $\mathrm{NO}_{3}{ }^{-}$and $\mathrm{NO}_{2}^{-}$Ion Concentrations on the Photodegradation Process}

In the course of our research, we evaluated the consequence of $\mathrm{NO}_{3}^{-}$ions present for the rate of photodegradation of paracetamol, naproxen, and diclofenac. For this purpose three concentration levels of the ions were used: 20,40 , and $70 \mathrm{molL}^{-1}$, the concentration values having been chosen with regard to those used in relevant literature sources. In particular, nitrate ions are prevalent in surface waters in concentrations between 21 and $70 \mathrm{mgL}^{-1}$. During the experiment, $50 \mathrm{ml}$ laboratory flasks were filled with small volumes of double-distilled water in which proper analytical weighed amounts of $\mathrm{KNO}_{3}$ were dissolved. Then, for each of the analyzed drug we added $25 \mathrm{ml}$ volume of its working solution at a concentration of $10^{-4} \mathrm{molL}^{-1}$; later, every flask was filled with double-distilled water and the prepared mixtures were transferred to crystallizing dishes and put in the chamber of the solar radiation simulator. Next, the solutions were irradiated for 120 minutes, and every 10 minutes the process was interrupted to take a $2 \mathrm{ml}$ sample and register its absorption spectrum. Concurrently to the working solution of a drug, a reference solution containing $\mathrm{NO}_{3}^{-}$ ions only was also subjected to irradiation. In the outcome, in the paracetamol solution no apparent acceleration of the decomposition process could be noted. The same, however, cannot be said of naproxen and diclofenac: in their cases, the presence of $\mathrm{NO}_{3}^{-}$ions had a photosensitizing effect. For both these drugs the reaction proceeded with great intensity during the initial 30-40 minutes, slowing down notably in the later period. It should be added here that the presence of $\mathrm{NO}_{2}{ }^{-}$ions affected the processes in a similar manner. The detailed results of the above experiments are provided in Table 2. The observed effect could be related to the photochemical transformation of nitrate ions [14]. Its irradiation by UV-light (maximum $302 \mathrm{~nm}$ ) causes the following chain of reactions:

$$
\begin{gathered}
\mathrm{NO}_{3}^{-}+\text {light } \rightarrow \mathrm{NO}_{3}^{-*} \\
\mathrm{NO}_{3}^{-*} \rightarrow \mathrm{NO}^{2-}+\mathrm{O}\left({ }^{3} \mathrm{P}\right) \\
\mathrm{NO}_{3}^{-*} \rightarrow \mathrm{NO}_{2}+\cdot \mathrm{O}^{-} \\
\cdot \mathrm{O}^{-}+\mathrm{H}_{2} \mathrm{O} \rightarrow \cdot \mathrm{OH}+\mathrm{OH}^{-}
\end{gathered}
$$

...which is one of the sources of hydroxyl radicals [34]. The increase in the amount of a strong oxidant like $\mathrm{OH}$ radicals resulted in an increasing decomposition rates for naproxen and diclofenac. 


\section{Influence of Humic Acids}

In the following step we assayed the effect of humic acids on the course of photodegradation of paracetamol, naproxen, and diclofenac. The concentration of the humic acids used for this purpose was $20 \mu \mathrm{g} \mathrm{mL}^{-1}$, i.e., such as is characteristic of unpolluted surface waters. The observation was made that the presence of organic matter drastically changed the processes of photodegradation of the drugs in question. For instance, as far as paracetamol was concerned, in the existence of humic acid the reaction failed to occur at all. In the case of naproxen, the pace of the reaction was 3-4 times lower in comparison to pure solutions. On the other hand, the decomposition of diclofenac proceeded faster in the first period of irradiation (Table 2). The acceleration of rate of diclofenac degradation in the presence of the humic substances can be explained by their action as photosensitizers. But on the other hand, humic substances act as inner light filters, decreasing the depth of penetration of light and decreasing the number of photons available for other organic compounds [14].

\section{Photodecomposition Kinetics of Paracetamol, Naproxen, and Diclofenac in the Presence of Natural Matrices}

Finally, we considered the impact of natural matrices on the processes of photodegradation of paracetamol, naproxen, and diclofenac. We used a certified sample of Grand River water along with a sample of treated municipal waste obtained from a local sewage treatment plant. Chemical characteristics of the certified sample are provided in Table 3, and Table 4 shows maximum values of the chemical parameters that should be exhibited by treated municipal waste.

On the whole, it was established that the presence of the certified material had an inhibitory impact on photodecomposition of paracetamol and naproxen. In the case of paracetamol, the progress of reaction was negligible, and naproxen decomposed approximately twice as slowly as its pure solution. Interestingly enough, for diclofenac the components of the CRM acted as a photosensitizer: increased rate of the process was observed, and the half-life decreased by one half. In the next step of this experiment we studied the photodegradation of the drugs in the presence of a complex matrix constituted by treated municipal waste. The parameters characterizing the waste are offered in Table 4. In the course of the test, it transpired that the complex matrix had a greatly photosensitizing effect. Essentially, photodegradation proceeded quickly for all the analyzed drugs. The obtained data are collected in Table 2. Accordingly, paracetamol underwent complete decomposition after 90 minutes, while naproxen and diclofenac after respectively 100 and 120 minutes. Such results indicated that the processes of photodecomposition of the drugs in the presence of an organic matrix occurred through intermediary photochemical reactions. This phenomenon could be explained through the degradation of studied pharmaceuticals being promoted by the presence
Table 3. Chemical characteristics of used CRM.

\begin{tabular}{|c|c|}
\hline Parameter & Value $/ \mathrm{mg} \mathrm{L}^{-1}$ \\
\hline Basicity & 184 \\
\hline $\mathrm{NH}_{3}$ & 0.02 \\
\hline B & 0.06 \\
\hline $\mathrm{Ca}$ & 90 \\
\hline $\mathrm{Cl}$ & 93 \\
\hline Colour (Hazen units) & 16 \\
\hline Dissolved Inorganic Carbon & 42.7 \\
\hline Dissolved Organic Carbon & 4.9 \\
\hline $\mathrm{F}$ & 0.16 \\
\hline Hardness & 336 \\
\hline $\mathrm{Mg}$ & 25.7 \\
\hline $\mathrm{pH}$ & 8.3 \\
\hline $\mathrm{NO}_{3}^{-}+\mathrm{NO}_{2}^{-}$ & 4.3 \\
\hline K & 4 \\
\hline $\mathrm{Si}$ & 1.16 \\
\hline $\mathrm{Na}$ & 48.6 \\
\hline Conductivity /mS & 860 \\
\hline $\mathrm{SO}_{4}^{2-}$ & 110 \\
\hline Total nitrogen (Kjeldahl's method) & 0.52 \\
\hline Turbidity & 0.09 \\
\hline
\end{tabular}

Table 4. Characteristics of treated municipal waste.

\begin{tabular}{|c|c|c|}
\hline Parameter & Unit & Value \\
\hline $\begin{array}{c}\text { Five days oxygen demand (FDOD } \\
\text { determined with the addition of } \\
\text { a nitrification inhibitor }\end{array}$ & $\mathrm{mg} \mathrm{O}_{2} \mathrm{~L}^{-1}$ & 15 \\
\hline $\begin{array}{c}\text { Chemical oxygen demand (ChODCr) } \\
\text { determined by the dichromate method }\end{array}$ & $\mathrm{mg} \mathrm{O}_{2} \mathrm{~L}^{-1}$ & 125 \\
\hline
\end{tabular}

of free radicals generated by irradiation of matrix rich in organic substances. This effect is especially evident in the case of paracetamol.

\section{Conclusion}

The conducted experiments were directed at establishing factors relevant for the lifetime of drugs in water environments. The obtained results showed that the transformation of organic substances in aqueous environment is a very complex process. The analysis of influence of an individual environmental factor did not provide information about the persistence of organic compound in aqueous environments. The experiments provided with the use of a sample of treated municipal 
waste showed that the matrix constituents have a synergistic effect on photodegradation of all studied pharmaceuticals. Paracetamol, in principle, turns out to be a stable, photoresistant compound. Its rapid degeneration in the presence of a matrix rich in organic compounds implies that the photodecomposition proceeds by means of intermediary photochemical mechanisms. This suggests the involvement of hydroxyl radicals in paracetamol degradation $[35,36]$. Both naproxen and diclofenac [12], on the other hand, are photosensitive drugs, degenerating already after 10 minutes of irradiation. The provided experiments proved that naproxen decomposed mainly by direct photolysis process. The addition of humic substances into laboratory solution resulted in inhibition of its decomposition. But the results obtained for the matrix rich in organic substances showed that radical reaction is very important for its degradation. It was found that diclofenac is subjected to direct photolysis as well as undergoing the photosensitized reaction in the presence of organic matter. The photoproducts of naproxen and diclofenac ensuing in the reaction of photodegradation are photosensitive too. Generally, the kinetics of their further photodecomposition are determined by the intensity of light and the existence of organic photosensitizers in their surroundings.

\section{References}

1. KHETAN S.K., COLLINS T. J. Human pharmaceuticals in the aquatic environment: a challenge to green chemistry. Chem. Rev. 107, 2319, 2007.

2. JIANG J.-Q., ZHOU Z., SHARMA V.K. Occurrence, transportation, monitoring and treatment of emerging micropollutants in waste water - A review from global views Microchem. J. 110, 292, 2013.

3. COLLADO N., RODRIGUEZ-MOZAZ S., GROS M., RUBIROLA A., BARCELO D., COMAS J., RODRIGUEZRODA I., BUTTIGLIERI G., Pharmaceuticals occurrence in a WWTP with significant industrial contribution and its input into the river system. Environ Pollut. 185, 202, 2014.

4. RICHARDSON S.D. Environmental mass spectrometry: Emerging contaminants and current issues. Anal. Chem. 84, 747, 2012.

5. GAUTAM A.K., KUMAR S., SABUMON P.C. Preliminary study of physico-chemical treatment options for hospital wastewater. J. Environ. Manag. 83, 298, 2007.

6. LIU J.L., WONG M.-H. Pharmaceuticals and personal care products (PPCPs): A review on environmental contamination in China. Environ. Int. 59, 208, 2013.

7. MUSSON E., TOWNSEND T.G. Pharmaceutical compound content of municipal solid waste. J. Hazard. Mater. 162, 730, 2009.

8. KUNKEL U., RADKE M. Fate of pharmaceuticals in rivers: Deriving a benchmark dataset at favorable attenuation conditions. Water Res. 46, 5551, 2012.

9. NEBOT I.C., VAZQUEZ B.I., MIRANDA J.M., ABUIN C.M.F., CEPEDA A. Detection of veterinary drug residues in surface waters collected nearby farming areas in Galicia, North of Spain. Environ. Sci. Pollut. Res. 21, 2367, 2014.

10. SPURGEON D.J., JONES O.A.H.,. DORNE J.-L.C.M, SVENDSEN C., SWAIN S., STURZENBAUM S.R.
Systems toxicology approaches for understanding the joint effects of environmental chemical mixtures. Sci. Total Environ. 408, 3725, 2010.

11. HOTCHKISS A.K., RIDER C.V., BLYSTONE C.R., WILSON V.S., HARTIG P.C., ANLKEY G.T., FOSTER P.M., GRAY C.L., GRAY L.E. Fifteen Years after "Wingspread" - Environmental Endocrine Disrupters and Human and Wildlife Health: Where We are Today and Where We Need to Go. Toxicol. Sci. 105, 235, 2008.

12. WANG X.-H., YU-CHEN LIN A. Is the phototransformation of pharmaceuticals a natural purification process that decreases ecological and human health risks? Environ. Pollut. 186, 203, 2014.

13. CHALLIS J.K., HANSON M.L., FRIESEN K.J., WONG CH.S. A critical assessment of the photodegradation of pharmaceuticals in aquatic environments: defining our current understanding and identifying knowledge gaps. Environ. Sci.: Processes Impacts 16, 672, 2014.

14. ZEPP R.G., SCHLOTZHAUER P.F., SINK M. Photosensitized transformations involving electronic energy transfer in natural waters: role of humic substances. Environ. Sci. Technol. 19, 74, 1985.

15. FARRE M., PETROVIC M., GROS M., KOSJEK T., MARTINEZ E., HEATH E., OSVALD P., LOOS R., LE MENACH K., BUDZINSKI H., DE ALENCASTRO F., MULLER J., KNEPPER T., FINK G., TERNES T.A., ZUCCATO E., KORMALI P., GANS O., QUITANA J.B., PASTORI F., GENTILI A., BARCELO D. First interlaboratory exercise on non-steroidal anti-inflammatory drugs analysis in environmental samples. Talanta 76, 580, 2008.

16. LISOWSKA B., RELL-BAKARALSKA M., RUTKOWSKA-SAK L. Niesteroidowe leki przeciwzapalne - blaski i cienie. Reumatologia 44, 106, 2006.

17. MÉNDEZ-ARRIAGA F., ESPLUGAS S., GIMÉNEZ J. Photocatalytic degradation of non-steroidal antiinflammatory drugs with $\mathrm{TiO}_{2}$ and simulated solar irradiation. Water Res. 42, 585, 2008.

18. SANTOS L.H.M.L.M., ARANJO A.N., FACHINI A., Ecotoxicological aspects related to the presence of pharmaceuticals in the aquatic environment. J. Hazard. Mater. 175, 45, 2010.

19. LANDRY K. A., BOYER T. H. Diclofenac removal in urine using strong-base anion exchange polymer resins. Water Res. 47, 6432, 2013.

20. YAMAMOTO H., NAKAMURA Y., MORIGUCHI S. Persistence and partitioning of eight selected pharmaceuticals in the aquatic environment: Laboratory photolysis, biodegradation, and sorption experiments. Water Res., 43, 351, 2009.

21. SALEH A., LARSSON E., YAMINI Y., JONSSON J.A. Hollow fiber liquid phase microextraction as a preconcentration and clean-up step after pressurized hot water extraction for the determination of non-steroidal anti-inflammatory drugs in sewage sludge. J. Chromatogr. A 1218, 1331, 2011.

22. BORECKA M., SIEDLEWICZ G., HALIŃSKI Ł. P., SIKORA K., PAZDRO K., STEPNOWSKI P., BIAŁKBIELIŃSKA A. Contamination of the southern Baltic Sea waters by the residues of selected pharmaceuticals: Method development and field studies. Marine Poll. Bull. 94, 62, 2015.

23. ANDREOZZI R., RAFFAELE M., NICLAS P. Pharmaceuticals in STP effluents and their solar photodegradation in aquatic environment. Chemosphere 50, 1319, 2003.

24. BOYD G.R., REEMTSMA H., GRIMM D.A., MITRA S. Pharmaceuticals and personal care products (PPCPs) in 
surface and treated waters of Louisiana, USA and Ontario, Canada. Sci. Total. Environ. 311, 135, 2003.

25. CASTIGLIONI S., BAGNATI R., CALAMARI D., FANELLI R., ZUCCATO E. A multiresidue analytical method using solid-phase extraction and high-pressure liquid chromatography tandem mass spectrometry to measure pharmaceuticals of different therapeutic classes in urban wastewaters. J. Chromatogr. A 1092, 206, 2005.

26. MEIERJOHANN A., BROZINSKI J.M., KRONBERG L. Seasonal variation of pharmaceutical concentrations in a river/lake system in Eastern Finland. Environ. Sci., 2016, DOI: 10.1039/C5EM00505A.

27. VIENO N.M., TUHKANEN T., KRONBERG L. Seasonal Variation in the Occurrence of Pharmaceuticals in Effluents from a Sewage Treatment Plant and in the Recipient Water. Environ. Sci. Technol. 39, 8220, 2005.

28. GRACIA-LOR E., SANCHO J.V., HERNANDEZ F. Simultaneous determination of acidic, neutral and basic pharmaceuticals in urban wastewater by ultra high-pressure liquid chromatography-tandem mass spectrometry. J. Chromatogr. A 1217, 622, 2010.

29. DĘBSKA J., KOT-WASIK A., NAMIEŚNIK J. Determination of nonsteroidal anti-inflammatory drug in water samples using liquid chromatography coupled with diode-array detector and mass spectrometry. Sep. Sci. 28 (17), 2419, 2005.

30. KASPRZYK-HORDERN B., DĄBROWSKA A., VIENO N., KRONBERG L., NAWROCKI J. Occurrence of acidic pharmaceuticals in river Warta in Poland. Chem. Anal. (Warsaw) 53, 289, 2008.

31. ZHANG Y., GEIßEN S.-U., GAL C. Carbamazepine and diclofenac: Removal in wastewater treatment plants and occurrence in water bodies. Chemosphere 73 (8), 1151, 2008.

32. ERIKSSON J., SVANFELT J., KRONBERG L. A Photochemical Study of Diclofenac and Its Major Transformation Products. Photochem. Photobiol. 86, 528, 2010.

33. SZYCHLINSKI J., BILSKI P., MARTUSZEWSKI K., BLAZEJOWSKI J. Complementary study on the use of the potassium Reinecke's salt as a chemical actinometer. The Analyst 114, 739, 1989.

34. GUANG-LONG LIU, LI GONG, LIANG HU, DUAN-WEI ZHU, XIU-YUN CAO, CHUN-LEI SONG, YI-YONG ZHOU. $\mathrm{NO}_{3}{ }^{-} / \mathrm{NO}_{2}^{-}$photosensitized degradation of phenol under simulated sunlight. Fres Environ. Bull. 24 (2a), 664, 2015.

35. YAMAL-TURBAY E., ORTEGA E., CONTE L.O., GRAELLS M., MANSILLA H.D., ALFANO O.M., PEREZ-MOYA M., Photonic efficiency of the photodegradation of paracetamol in water by the photo-Fenton process. Environ. Sci. Pollut. Res. 22, 938, 2015.

36. WU S., ZHANG L., CHEN J. Paracetamol in the environment and its degradation by microorganisms. Appl. Microbiol. Biotechnol. 96, 875, 2012. 